\title{
Improvement of Teacher Competence in Making Android-Based Evaluation Instruments at the AT Tohari Foundation, Semarang Regency
}

\author{
Tutik Wijayanti ${ }^{1, *}$ Maman Rachman $^{2}$ Dwi Hermawan ${ }^{3}$ Hendri $\operatorname{Irawan}^{4}$ \\ ${ }^{1,2,4}$ Faculty of Social Sciences, Semarang State University \\ ${ }^{3}$ Public Relations Center, Semarang State University \\ *Corresponding author.Email: tutikwijayanti@mail.unnes.ac.id
}

\begin{abstract}
Coronavirus Disease 2019 or COVID-19 has infected millions of people in more than 210 countries in the world. COVID19 caused many deaths. The COVID-19 pandemic affects almost all aspects of life, including education. Education and learning in many countries must be implemented online which greatly impacts the process of delivering materials and evaluating learning. Responding to these changes, teachers are required can to evaluate learning by adjusting the existing approach, namely the distance approach. This is done considering that evaluation has an important role to determine the success of students in mastering predetermined competencies. In connection with these needs, teachers are expected can develop based learning evaluations android by adjusting the development of Information Technology (IT). Therefore, it is necessary to have a competency improvement program and mentoring for teachers in making-based learning evaluation instruments android. The-based instrument android can be in the form of an application program, one of which is the Quiz Star Mobile Apps. Understanding the urgency and need, the schools assisted by the At Tohari Foundation in Semarang Regency have partners in improving teacher competence, including in making evaluation instruments. The partner is Semarang State University (UNNES) which provides assistance and training in making-based evaluation instruments android. This study seeks to explore more deeply related to the implementation of increasing teacher competence in makingbased evaluation instruments android at the At Tohari Foundation, Semarang Regency; and knowing the driving and inhibiting factors for the implementation of increasing teacher competence in making-based evaluation instruments android at the At Tohari Foundation, Semarang Regency. The approach used in this study is qualitative. The research location chosen was SMP Islam Plus At Tohari Semarang Regency. Sources of data used in this study include primary and secondary data sources. The techniques used in data collection are interviews, documentation, and observation. Data validity testing was carried out through informant reviews, member checks, and triangulation. Data were analyzed using interactive analysis techniques through the stages of data collection, data reduction, data display, and conclusions (verification).
\end{abstract}

Keywords: COVID-19, Evaluation Instruments, Quiz Star Mobile Apps, Teacher Competence.

\section{INTRODUCTION}

Coronavirus Disease 2019 or COVID-19 has infected millions of people in more than 200 countries around the world and caused many deaths [29][33][72]. The disease caused by Severe Acute Respiratory Syndrome-Coronavirus 2 or SARS-CoV-2 was first reported in Wuhan City, Hubei Province, China [29][31][32][45][56][69]. The World Health
Organization (WHO) has designated COVID-19 as a global pandemic [15][34][35][52][70].

The COVID-19 pandemic affects almost all aspects of life, including education $[4][7][17][18][20][21][38][67][71][73][78]$. In pandemic conditions, the role and position of the educational aspect are very crucial [8][9][25][46][74]. To break the chain of the spread of COVID-19 where students can act as carriers and spreaders of the disease without symptoms, 
almost all countries have eliminated activities in schools. As of April 2020, more than 400 million students worldwide are required to study at home [18][19][65].

The consequence of closing educational institutions physically and replacing them with learning at/from home as a government policy is a change in the teaching and learning system[6]. School managers, students, parents, and of course teachers must migrate to digital learning systems online, which is better known as elearning [2][26][63] or known as deep learning. network or "online learning" in Indonesia. Simultaneously, most educational institutions choose online learning options [7][10][20][36][58][59][62][64][67][73][78]. Indonesia is also relatively no different from other countries. Despite realizing that there are disparities in access to learning technology and various backgrounds of parents, the Ministry of Education and Culture of the Republic of Indonesia firmly enforces online learning policies[23][27][28][37][48][68].

Changes in learning and teaching patterns will certainly never be separated from the role of teachers[14][41][60][76], especially changes to online learning patterns. Teachers must be prepared for various learning conditions and student conditions, including the development of life in society [1][16][77].Online learning greatly impacts the process of delivering material and evaluating learning. Responding to these changes, teachers are required to be able to evaluate learning by adjusting existing approaches, namely distance or online approaches. This is done considering that evaluation plays a significant role in the learning process. Through evaluation, the success of students in the mastery of predetermined competencies[30]. Evaluation can be done through tests or non-tests. The device used can vary. One of the tools that can be used especially during a pandemic like this time is an an-based evaluation android by adjusting the development of Information Technology (IT). In today's global and modern context, it cannot be denied that IT in education cannot be separated. IT is one of the important means of building quality education and at the same time accelerating significant changes in building knowledge students'[3]. IT is simply often identified as a convenience and practicality, one of which is a smartphone or smartphone.

The survey results published by eMarketer, it is estimated that by the end of 2015 the number of users smartphone in Indonesia will increase to reach 55 million users[22]. eMarketer publishes that the number of users smartphone in Indonesia has increased to reach $37.1 \%$ from 2016-2019. After a re-survey, eMarketer republished the number of smartphone users from 2015 there were 65.2 million smartphone users, from 2016 there was 65.2 million users smartphone, from 2017 there was 74.9 million users smartphone, and in 2018 there were 83, 5 million users smartphone in Indonesia, it is estimated that in 2019 there will be 92 million users smartphone[75]. When associated with the education sector, smartphones can be used to improve the quality of education to be more attractive and motivate students to learn more creatively and innovatively, then increase student enthusiasm for learning. Likewise, if it is used as an evaluation model, it will certainly have a positive impact[47]. The positive impacts of the-based learning evaluation model android include: the implementation of the evaluation becomes more effective, efficient, and attractive; stimulate students' creative thinking power; and save more paper usage[40].

The position of-based evaluation is android very important in the design of the implementation of learning, especially in a pandemic like this time. Every educator should be able to master the techniques in making this learning evaluation instrument. The development of smartphones in the world has stimulated the emergence of various applications that can be used in the world of education. One such application is the Quiz Star Mobile Apps which is an application for creating questions, quizzes, or tests online (based on android). The use of Quiz Star Mobile Apps in making these questions is very friendly, so it is very easy to use and does not require programming language skills that are difficult to operate.

The number of applications that can be used by educators in making-based evaluation tools android should be able to assist educators in developing learning evaluation tools. Besides, the large number of teachers and students who use smartphones and the availability of network facilities wifi in schools should be able to support teachers in developing-based evaluation instruments android. However, the reality is that in Indonesia, there are still few educators who master how to make-based evaluation instruments android. Therefore, the schools assisted by the At Tohari Foundation in Semarang Regency have partners in improving teacher competence, one of which is in making evaluation instruments based on android. Their partner is the Semarang State University (UNNES) which provides assistance and training in making-based evaluation instruments android. This study seeks to explore more deeply related to the implementation of increasing teacher competence in making android-based evaluation instruments at the At Tohari Foundation, Semarang Regency; and knowing the driving and inhibiting factors for the implementation of increasing teacher competence in making android-based evaluation instruments at the At Tohari Foundation, Semarang Regency. 


\section{LITERATURE REVIEW}

\subsection{Learning During the Covid-19 Pandemic}

The world is struggling against COVID-19, educational institutions must quickly anticipate [51]. As was done in the influenza pandemic, the practice most often applied by schools is canceling or postponing learning activities at school, canceling classes or activities with high levels of mixing that happen during learning hours, and reducing physical interactions while using transportation (Uscher -Pines et al., 2018). Educational institutions in the world must be temporarily closed, following government instructions in their respective countries, thus affecting the academic system. They must find new alternatives to implement learning, and virtual classroom / online learning is the most likely way forward[6].

In the United States, for example, the state of Arizona has issued a "Pandemic Preparedness" guide that includes online learning as a solution for educational institutions. According to the Arizona Department of Education (2020)[5] in the sub-section "Continuity of Education Instruction" it has been emphasized that it is important to maintain learning and to involve students in positive activities when they are not in school. Involving learners at any level will give them a sense of normality during a crisis, as well as provide constructive solutions to learning interactions. Maintaining routine activities during an emergency is a positive response step that helps speed recovery after a crisis. Continuity of education during a pandemic will depend on various factors, such as the level of school preparation, the readiness of parents/families, and the readiness of teachers. Consideration must be given to the need for all students to continue providing education during the onset of the pandemic. In addition to using copies of teaching materials, such as books, workbooks, and other documents sent by post or courier, schools can use various technology-based solutions to increase the likelihood that students can continue their learning activities.

Schools in Indonesia have been trying to implement online learning. Teachers and students are progressively familiar with the technology used for online learning. The apps used are Zoom Cloud Meeting, Google Classroom, Google Form, WhatsApp Group, and e-mail. Teachers and students use these various locations according to their respective conditions and abilities. Schools use technological developments to get around unexpected situations that affect teaching and learning activities, including the COVID-19 pandemic[61]. Melania (2020)[39] has surveyed students who carry out online learning activities. The results show that some students accept online learning because it is more relaxed, fun, flexible, efficient, short, practical, fast, precise, safe, easy, timesaving, and energy efficient.

\subsection{Improvement of Teacher Competence}

The world is developing so fast. Everything that could not be done at first is suddenly shocked by other people who can do it. So that we are not left behind and left behind by a rapidly changing era, we are aware that education is very important. Therefore, a professional teacher is needed. Professional teachers are required to master a set of basic competencies or abilities that enable these teachers to carry out their duties properly. In the National Education Standards, the explanation of article 28 paragraph 3 states that pedagogical competence is the ability to manage student learning. It is including the understanding of students, designing and implementing learning, evaluating learning outcomes, and developing students. Pedagogic competence is a competency that typically characterizes and differentiates the teaching profession from other professions. Mastery of developmental theory and learning theories rests with the teacher. So, it is necessary to grow awareness that mastery of student development materials, learning theories, curriculum development, evaluation techniques, mastery of teaching models and methods, is necessary for addition to mastery of subjects and science and technology related to teaching. One of the efforts that can be done is by optimizing the role of the principal. Besides, teachers must also master several aspects of pedagogical competence. Nur (2020)[42] explains that the aspects of pedagogical competencies that a teacher must master are as follows:

(1) Mastering the characteristics of students

Understanding students is one of the pedagogic competencies that teachers must have. There are at least four things namely the level of intelligence, creativity, physical disabilities, and cognitive development. Mastering learning theory and educational principles of learning. Teachers can determine various approaches, strategies, methods, and teaching-learning techniques.

(2) Curriculum development

Teachers can develop a national education curriculum adapted to the specific conditions of the school environment.

(3) Educational learning activities

One of the pedagogical competencies that teachers must have as formulated in the NSP is related to the implementation of learning. The main task of the teacher is to condition the environment to support changes in behavior and the formation of student competencies.

(4) Development of the potential of students 
The development of students is part of the pedagogical competencies that teachers must have, to actualize the various potentials possessed by each student.

(5) Communication with students

The teacher can communicate effectively, empathically, and politely with students and is enthusiastic and positive. Teachers can provide complete and relevant responses.

(6) Assessment and evaluation

Evaluation of learning outcomes is carried out to determine changes in behavior and the formation of student competencies, which can be done with class assessments, basic ability tests.

Pedagogic competence is a fundamental competence in the implementation of the learning process. In this study, the study focused on the pedagogical ability of teachers in providing assessment and evaluation. The teacher must be able to carry out an assessment of the process and learning outcomes on an ongoing basis. Teachers must be able to evaluate the effectiveness of the process and learning outcomes and use the information from the assessment and evaluation results to design remedial and enrichment programs.

\subsection{Android-Based Evaluation Instruments}

The use of media in learning can help the limitations of educators in taking information as well as limited class hours, especially during a pandemic like this time. The media serves as a source of information on learning materials and a source of practice questions. The quality of learning is also influenced by individual differences in students, both differences in learning styles, differences in cognitive abilities, differences in learning speed, and differences in backgrounds. Learning media can be made and considered by current technological developments. Technology and information-assisted learning media (ICT) can be used to make learning interesting and have a positive impact on academic performance in the form of learning motivation and student learning outcomes[13]. The use of ICT-assisted learning media can make learning more effective as stated by Diedren [48][57]. The use of ICT-assisted learning media can also facilitate the implementation of learning as desired by Government Regulation No.32 of 2013 article 19 paragraph (1) which states that learning activities in educational units are held in an interactive, fun, inspiring, challenging, and motivating way for students.

One of the ICT-assisted learning media that can be used is in the formula of learning media that is operated on a device smartphone with an operating system Android. Currently, the operating system Android is the most popular operating system and is widely used by the public, especially among students. The use of-based learning media Android is one of the applications of $21 \mathrm{st}-$ century learning styles [11]. The use of this type of learning media has the potential to help improve the academic performance of students in the form of learning outcomes in the cognitive[12][24]. The implementation of learning using smartphones and tablets can have a positive impact on the cognitive, metacognitive, affective, and socio-cultural dimensions. Smartphones have the power to transform the learning understanding. This type of learning media lets students to learn not restricted by time and place with interesting apps[53].

Apart from being used as a learning medium and delivering material, android can also be used as a learning evaluation instrument. Through mentoring school partners and developing the application program Quiz Star Mobile Apps, teachers of SMP Islam Plus At Tohari are expected to have additional competencies in conducting learning evaluations, especially those based on the Android operating system. The Quiz Star Mobile Apps application program is an application for creating quizzes, questions, or online tests. The use of Quiz Star Mobile Apps in making these questions is very friendly, so it is very easy to use and does not need programming skills that are difficult to function.

\section{RESEARCH METHOD}

The approach used in this study is qualitative. Qualitative research is research that conducts analysis and interpretation of texts and the results of interviews to find the meaning of a phenomenon (Auerbach and Silverstein; [55]. The location of this research is in SMP at the AT Tohari Foundation, Semarang Regency. Sources of data used in this study are (1). Principals, teachers, and students. (2). Activities in SMP at the At Tohari Foundation, (3). Available documents. Techniques used in data collection include interviews, documentation, and observation. Data collection tools used include interview guidelines, field notes, and observation sheets. Data validity testing was carried out by informant review, member check (peer examination), and triangulation. Triangulations conducted are triangulation of sources (informants, events, documents), and triangulation of tools (interviews, observations, and documentation). The analysis technique used is interactive analysis with data collection, data reduction, display data, and conclusions. 


\section{RESULTS AND DISCUSSION}

\subsection{Improvement of Teacher Competence in Making Android-based Evaluation Instruments}

AT Tohari Foundation is a foundation boarding school where there are formal schools as well as Islamic boarding schools for students. At the time of the COVID19 pandemic, this school continued to carry out execute learning by paying attention to health protocols. This is still done because the Foundation is a green zone, where it is still safe enough to execute face-to-face learning. However, the implementation of health protocols is still being implemented to anticipate a pandemic. In the learning process during the pandemic, even though this Foundation uses a face-to-face school model, efforts to prepare themselves if later schools are to be carried out online are also carried out by the school. One of the efforts to increase teacher competence carried out by the school is by providing training to educators in making Android-based learning media, including the evaluation model. Evaluation is one of the most important components in the learning process because, through evaluation, the success of the learning process can be known[56]. The evaluation model that must be carried out by an educator, of course, must adjust to the learning model used. In the Android-based learning model, of course, the evaluation model must also adjust to this model, namely by using an Android-based evaluation model as well. To improve the competence of educators at At Tohari Foundation in making android-based evaluation instruments, the school collaborated with school partners from Semarang State University to provide intensive training. The stages carried out in increasing the competence of educators at the At Tohari Foundation, as follows:

\subsubsection{Socialization Stage}

At the socialization stage, the delivery of material related to the importance of learning instruments, how to prepare good and correct instructions, and the use of technology in education, especially as a medium that makes it easier for teachers and students. After the delivery of material related to evaluation, it is followed by the delivery of material related to the use of technology as a means of making evaluation instruments. In the presentation related to this material, the resource person (the school partner team) explained the use of technology in everyday life that has become a human need. This can be seen from the use of technology in Indonesia, which reaches $90 \%$ of Indonesia's population. Besides, the resource person also introduced an application that can be used for making evaluation instruments, namely through the application program, Quiz Star Mobile Apps which is an Android-based learning application. This application is designed for learning to make it more interesting and simplify the learning process. Besides, this application also has an evaluation feature, where the teacher can make questions that can later be tested on students online.

\subsubsection{Practical Application Use}

The next stage to improve teacher competence at At Tohari Foundation is to train teachers to use the application, starting from how to download it in the application Google Play store, how to $\log$ in to the application and use it on each menu. After the initial introduction of the application, then the teachers are asked to make questions that are entered into the application. Each teacher is asked in turn to be able to log in to the application as a student and is asked to try to work on the questions that have been inputted by another teacher. Teachers are logged in as a teacher was asked to check and practice how to see the value you get out of the workmanship other fellow teachers. At this stage mentoring was carried out intensively by the resource persons and to facilitate the implementation of application usage practices, the teacher was given manual/instructions for using the application.

\subsubsection{Question and Answer / Discussion}

The implementation of the next activity is a question-and-answer session/discussion by the teachers to the resource persons and other participants. In this session, the teacher is shown to give questions to two presenters or to provide criticism and suggestions related to the implementation of mentoring.

\subsection{Supporting and Inhibiting Factors for Increasing Teacher Competence in Making Android-Based Evaluation Instruments}

Efforts to improve teacher competence in making android-based evaluation instruments can be carried out well because they are supported by the presence of teachers who are still young and have sufficient competence in the use of IT. Besides, the enthusiasm and motivation that is high enough to improve the competence of the teachers are also very good. The facilities and infrastructure provided by the school are also quite good, thus facilitating efforts to improve teacher competence. However, there are several obstacles faced in efforts to improve teacher competence in making 
android-based evaluation instruments. The obstacles faced are that not all students use Android, so even though the teacher is quite capable of making an Android-based evaluation instrument, the devices used by students must also support it so that the evaluation process can run well. Besides, applications that have been designed by school partners also still need further development so that the available features can be updated more, keeping up with the needs in the learning process and following the development of science and technology.

\section{CONCLUSION}

The use of learning media and evaluation instruments based on android is one of the learning styles apps of the 21 st century. It has the potential to help improve student academic performance of learning outcomes in the cognitive domain. This research concludes on two main things. First, the evaluation model that must be carried out by an educator, of course, must adjust to the learning model used. In the-based learning model Android, of course, the evaluation model must also adjust to this model, namely by using an an-based evaluation model as Android well. Increasing teacher competence in making-based evaluation instruments android at the At Tohari Foundation, Semarang Regency is carried out using the application program Quiz Star Mobile Apps. The stages carried out in increasing teacher competence include: (1) the socialization stage; (2) Application usage practices; and (3) Question and answer/discussion. Second, there are supporting factors in the implementation of increasing teacher competence in making-based evaluation instruments android at the At Tohari Foundation, Semarang Regency, namely: (1) Teachers who are still young and have sufficient competence in the use of IT; (2) enthusiasm and personal motivation high enough to increase the competence of teachers; (3) The facilities and infrastructure provided by the school are also quite good. However, there are several inhibiting factors in the implementation of increasing teacher competence in making android-based evaluation instruments at the At Tohari Foundation, Semarang Regency, namely: (1) Not all students use Android. Even though the teacher is quite capable of making-based evaluation instruments android, the tools used by students must also support so that the evaluation process can run well; (2) Applications that have been designed by school partners also still need further development so that the available features can be updated again, following the needs in the learning process, and following the development of science and technology.

\section{REFERENCES}

[1] Abdullah, R. (2016). Pembelajaran dalam perspektif kreativitas guru dalam pemanfaatan media pembelajaran. Lantanida Journal, 4(1), 35-49. https://doi.org/10.22373/lj.v4i1.1866

[2] Aderholt, R. (2020, March). Coronavirus outbreak shining an even brighter light on internet disparities in rural America. The Hill.

[3] Aisyah, S. (2011). Evaluasi Pembelajaran Berbasis IT dan Implikasinya terhadap Peningkatan Kualitas Pendidikan. Sosial Budaya, 8(1), 54-63.

[4] Anderson, J. (2020, March). Should schools close when coronavirus cases are still rare? Quartz.

[5] Arizona Department of Education. (2020). Pandemic preparedness (Issue March). Arizona Departmernt of Education.

[6] Arora, A. K., \& Srinivasan, R. (2020). Impact of pandemic COVID-19 on the teaching - learning process: A study of higher education teachers. Prabadhan: Indian Journal of Management, 13(4).https://doi.org/10.17010/pijom/2020/v13i4/15 1825

[7] Azzi-Huck, K., \& Shmis, T. (2020). Managing the impact of COVID-19 on education systems around the world: How countries are preparing, coping, and planning for recovery. World Bank Blogs.

[8] Bakhtiar, T. (2016). Optimal intervention strategies for cholera outbreak by education and chlorination. IOP Conference Series: Earth and Environmental Science, 31(1). https://doi.org/10.1088/1755$1315 / 31 / 1 / 012022$

[9] Barennes, H., Harimanana, A. N., Lorvongseng, S., Ongkhammy, S., \& Chu, C. (2010). Paradoxical risk perception and behaviours related to Avian Flu outbreak and education campaign, Laos. BMC Infectious Diseases, 10(March 2006). https://doi.org/10.1186/1471-2334-10-294

[10] Bartlett, J. D., Griffin, J., \& Thomson, D. (2020). Resources for supporting children's emotional wellbeing during the COVID-19 pandemic. Child Trend.

[11] Calimag, J. N., Mugel, P. A., Conde, R. S., \& Aquino, L. B. (2014). Ubquitous learning environment using android mobile application. International Journal of Research in Engineering \& Technology, 2 (2), 119-128.

[12] Chuang, T. Y., \& Chen, W. F. (2007). Effect of digital games on children's cognitive achievement. Journal of Multimedia, 2 (5), 27-30. 
[13]Chuang, Y. T. (2014). Increasing learning motivation and student engagement through the technology-supported learning environment. Creative Education, 5, 1969-1978.

[14] Collie, R. J., Shapka, J. D., \& Perry, N. E. (2011). Predicting teacher commitment: The impact of school climate and social-emotional learning. Psychology in the Schools, 48(10), 1034-1048. https://doi.org/10.1002/pits.20611

[15]Cucinotta, D., \& Vanelli, M. (2020). WHO declares COVID-19 a pandemic. Acta Bio-Medica: Atenei Parmensis, 91(1), 157-160. https://doi.org/10.23750/abm.v91i1.9397

[16] Darling-Hammond, L., \& John Bransford. (2005). Preparing teachers for a changing world: What teachers should learn and be able to do. Jossey-Bass. https://doi.org/10.5860/choice.43-1083

[17] DHEC. (2019). Higher education guidance on novel coronavirus or COVID-19 (Vol. 2019).

[18] Domenico, L. Di, Pullano, G., Coletti, P., Hens, N., \& Colizza, V. (2020). Expected impact of school closure and telework to mitigate COVID-19 epidemic in France.

[19]Gee, G. (2020). COVID-19: Impact on student predictions.

[20]Horn, M. B. (2020, March). COVID-19's long-term impacts on education in 2020 and beyond. EdSurge.

[21]Huang, R. H., Liu, D. J., Tlili, A., Yang, J. F., \& Wang, H. H. (2020). Handbook on facilitating flexible learning during educational disruption: The Chinese experience in maintaining undisrupted learning in COVID-19 Outbreak. In Smart Learning Institute of Beijing Normal University UNESCO.

[22] Idayati, R. (2011). Pengaruh Radiasi Handphone Terhadap Kesehatan. Jurnal Kedokteran Syiah Kuala.

https://doi.org/http://dx.doi.org/10.1016/j.ultsonch.2 011.07. 005

[23] Irawan, H. (2020). Inovasi pendidikan sebagai antisipasi penyebaran Covid-19 (Educational innovations anticipating the spread of [Covid-19]). In Ombudsman RI. Ombusman RI.

[24] Jabbour, K. K. (2014). An Analysis of the effect of mobile learning on lebanse higher education. Informatics in Education, 13 (1), 1-15.

[25] Karlsen, H., Mehli, L., Wahl, E., \& Staberg, R. L. (2015). Teaching outbreak investigation to undergraduate food technologists. British Food Journal, 117(2), 766-778. https://doi.org/10.1108/BFJ-02-2014-0062
[26] Karp, P., \& McGowan, M. (2020, March). "Clear as mud" schools ask for online learning help as coronavirus policy confusion persists Australia news. The Guardian.

[27] Katili, D. L. (2020). Belajar bahagia dalam bencana COVID-19 (Learn to be happy in the COVID-19 disaster). LPMP DKI Jakarta.

[28] Kemendikbud. (2020). Belajar dari rumah, satuan pendidikan dapat pilih platform pembelajaran jarak jauh sesuai kebutuhan (Learning from home, education units can choose distance learning platforms as needed). Kementerian Pendidikan dan Kebudayaan, Republik Indonesia.

[29] Khan, M., Kazmi, S., Bashir, A., \& Siddique, N. (2020). COVID-19 infection: Origin, transmission, and characteristics of human coronaviruses. Journal of Advanced Research, 24, 91-98. https://doi.org/10.1016/j.jare.2020.03.005

[30] Kunandar. 2013. Penilaian Autentik (Penilaian Hasil Belajar Peserta Didik Berdasarkan Kurikulum 2013). Jakarta: PT. Raja Grafindo Persada.

[31]Li, C., Yang, Y., \& Ren, L. (2020). Genetic evolution analysis of 2019 novel coronavirus and coronavirus from other species. Infection, Genetics and Evolution, 82 (March), 1-3. https://doi.org/10.1016/j.meegid.2020.104285

[32]Li, T., Lu, H., \& Zhang, W. (2020). Clinical observation and management of COVID-19 patients. Emerging Microbes \& Infections, 9(1), 687-690. https://doi.org/10.1080/22221751.2020.1741327

[33]Lin, Q., Zhao, S., Gao, D., Lou, Y., Yang, S., Musa, S. S., Wang, M. H., Cai, Y., Wang, W., Yang, L., \& He, D. (2020). A conceptual model for the coronavirus disease 2019 (COVID-19) outbreak in Wuhan, China with individual reaction and governmental action. International Journal of Infectious Diseases, 93, 211-216. https://doi.org/10.1016/j.ijid.2020.02.058

[34]Lloyd-Sherlock, P. G., Kalache, A., McKee, M., Derbyshire, J., Geffen, L., Casas, F. G.-O., \& Gutierrez, L. M. (2020). WHO must prioritise the needs of older people in its response to the covid-19 pandemic. BMJ (Clinical Research Ed.), 368(m1164), https://doi.org/10.1136/bmj.m1164

[35] Mahase, E. (2020). Covid-19: WHO declares pandemic because of "alarming levels" of spread, severity, and inaction. BMJ (Clinical Research Ed.), 368(m1036), 1. https://doi.org/10.1136/bmj.m1036

[36] Maine Department of Education. (2020). Coronavirus (COVID-19) resources for schools. Maine Department of Education. 
[37] Makdori, Y. (2020, April). Kemendikbud luncurkan platform guru berbagai untuk bantu pengajar lakukan pembelajaran daring (The Ministry of Education and Culture launches various teacher platforms to help teachers do online learning). Liputan 6.

[38] Meister, J. (2011). 2011: The Year of the media tablet as a learning tool. Proquest, 65 (4), 28-31.

[39] Melania, E. P. (2020, April). Pembelajaran daring, apakah efektif untuk Indonesia. Kompas.

[40] Nadya, Dhea. 2012. Diperlukan 1 Batang pohon Usia 5 Tahun untuk Memproduksi 1 Rim Kertas. http://www.kompasiana.com/dheanadya/diperlukan1-batang-pohon-usia5tahun-untuk-memproduksi-1rim kertas_550df44fa33311b12dba7e6c. (Diunduh tanggal 6 Februari 2020.)

[41]Najeemah M Yusof. (2012). School climate and teachers' commitment: A case study of Malaysia. International Journal of Economics Business and Management Studies, 1(2), 65-75.

[42]Nur, A.A., 2020. Meningkatkan kompetensi pedagogik guru di SD yayasan Mutiara Gambut. Jurnal Bahana Manajemen Pendidikan, 2(1), pp.65-72.

[43]Peraturan Pemerintah (PP) No.32 Tahun 2013. Perubahan Atas Peraturan Pemerintah Nomor 19 Tahun 2005 Tentang Standar Nasional Pendidikan.

[44]Peraturan Pemerintah No. 19 Tahun 2005 tentang Standar Nasional Pendidikan.

[45] Phan, T. (2020). Genetic diversity and evolution of SARS-CoV-2. Infection, Genetics and Evolution, 81(February), 104260. https://doi.org/10.1016/j.meegid.2020.104260

[46] Pogreba-Brown, K., Ernst, K., \& Harris, R. (2012). Teaching epidemiology concepts experientially: A "real" foodborne outbreak in the classroom. Public Health Reports, 127(5), 549-555. https://doi.org/10.1177/003335491212700512

[47] Purnamasari, Andrita. 2015. Pengembangan Alat Evaluasi Pembelajaran Berbasis Teknologi Informasi dan Komunikasi Dengan Wondershare Quiz Creator Materi Sistem Penilaian Persediaan. Jurnal Pendidikan. Volume 03 Nomor 01 Tahun 2015. Hal.216

[48] Putsanra, D. V. (2020). Daftar e-learning Kemendikbud, sekolah online untuk mencegah corona. Tirto.Id.

[49] Riyadi, S., \& Pardjono, P. (2014). Pengembangan multimedia pembelajaran matematika berbasis komputer untuk kelas VIII SMP. Jurnal Inovasi
Teknologi Pendidikan, 1(2). Retrieved from http://journal.uny.ac.id/index.php/jitp/article/view/2 527.

[50] Satriawan, Y. (2020, May). Hardiknas: Belajar di rumah, berdamai dengan tekonologi di tengah pandemi. VOA Indonesia.

[51] Snelling, J., \& Fingal, D. (2020). 10 Strategies for Online Learning During a Coronavirus Outbreak. Deas, Content and Resources for Leading-Edge Educators.

[52] Sohrabi, C., Alsafi, Z., Neill, N. O., Khan, M., Kerwan, A., Al-jabir, A., Iosifidis, C., \& Agha, R. (2020). World Health Organization declares global emergency: A review of the 2019 novel coronavirus (COVID-19). International Journal of Surgery, 76, 71-76. https://doi.org/10.1016/j.ijsu.2020.02.034

[53] Squire, K. (2009). Mobile media learning: multiplicities of place. On the Horizon, 17 (1), 7080.

[54] Su, L., Ma, X., Yu, H., Zhang, Z., Bian, P., Han, Y., Sun, J., Liu, Y., Yang, C., Geng, J., Zhang, Z., \& Gai, Z. (2020). The different clinical characteristics of corona virus disease cases between children and their families in China - the character of children with COVID-19. Emerging Microbes \& Infections, 9(1), 707-713.

https://doi.org/10.1080/22221751.2020.1744483

[55] Sugiyono. (2017). Metode Penelitian Pendidikan Pendekatan Kuantitatif, Kualitatif, Dan R\&D. Bandung : Alfabeta.

[56] Sunarto, S., Tijan, T., Wijayanti, T. and Lestari, E.Y., 2018, November. Development of Assessment Instrument for Social Care Character in Civic Education Course at Universitas Negeri Semarang. In Annual Civic Education Conference (ACEC 2018) (pp. 90-92). Atlantis Press.

[57] Sutrisno. (2011). Pengantar pembelajaran inovatif. Jakarta: Gaung Perkasa Press.

[58] The International Baccalaureate Organization. (2020). Online learning, teaching and education continuity planning for schools.

[59] The World Bank. (2020). Remote learning, EdTech \& COVID-19. BRIEF.

[60] Thien, L. M., Abd Razak, N., \& Ramayah, T. (2014). Validating teacher commitment scale using a Malaysian sample. SAGE Open, 4(2), 1-9. https://doi.org/10.1177/2158244014536744

[61]Tim Kompas. (2020). Era baru pendidikan di Indonesia. Kompas. 
[62] Ting, D. S. W., Carin, L., Dzau, V., \& Wong, T. Y. (2020). Digital technology and COVID-19. Nature Medicine. https://doi.org/10.1038/s41591-0200824-5

[63]UNESCO. (2020a). Distance learning solutions. UNESCO's COVID-19 Education Response.

[64]UNESCO. (2020b). Motivating learners during remote learning due to COVID-19 - Tips for teachers (p. 1). UNESCO.

[65]UNESCO. (2020c). School closures caused by Coronavirus (Covid-19). COVID-19 Educational Disruption and Response.

[66] Uscher-Pines, L., Schwartz, H. L., Ahmed, F., Zheteyeva, Y., Meza, E., Baker, G., \& Uzicanin, A. (2018). School practices to promote social distancing in K-12 schools: Review of influenza pandemic policies and practices. BMC Public Health, 18(1), 113. https://doi.org/10.1186/s12889-018-5302-3

[67] van Fleet, J. (2020). Education in the time of COVID-19. Global Partnership for Education.

[68] Wahyudi, N. (2020). Imbas pandemi virus corona bagi dunia pendidikan Indonesia dan global (The impact of the corona virus pandemic for the world of education in Indonesia and globally). Kumparan.

[69] Wang, H., Wang, Z., Dong, Y., Chang, R., Xu, C., Yu, X., Zhang, S., Tsamlag, L., Shang, M., Huang, J., Wang, Y., Xu, G., Shen, T., Zhang, X., \& Cai, Y. (2020). Phase-adjusted estimation of the number of Coronavirus Disease 2019 cases in Wuhan, China. Cell Discovery, 6(1), 4-11. https://doi.org/10.1038/s41421-020-0148-0

[70] Watkins, J. (2020). Preventing a covid-19 pandemic. The BMJ, 368(February), 1-2. https://doi.org/10.1136/bmj.m810

[71] World Health Organization. (2020). Key messages and actions for COVID-19 prevention and control in schools (L. Bender (ed.); Issue March). UNICEF.

[72] Worldometers. (2020). COVID-19 coronavirus pandemic. Coronavirus.

[73] Yan, W. (2020, March). How will COVID-19 impact global education. China Daily.

[74] Yang, J., Park, E. C., Lee, S. A., \& Lee, S. G. (2019). Associations between hand hygiene education and self-reported hand-washing behaviors among Korean adults during MERS-CoV outbreak. Health Education and Behavior, 46(1), 157-164. https://doi.org/10.1177/1090198118783829

[75] Yusmi, R. (2015). Pentingnya Pendampingan Dialogis Orangtua Dalam Penggunaan Gadget Pada
Anak Usia Dini. 3URVLGLQJ _ 6HPLQDU_ 1DVLRQDO_ 3HQGLGLNDQ_ ${ }^{3}, \mathrm{QRYDVL}_{-}$ Pembelajaran UQWXN_3HQGLGLNDQ_\%HUNHPDMXDQ_'

[76]Zacharo, K., Marios, K., \& Dimitra, P. (2018). Connection of teachers' organizational commitment and transformational leadership. A case study from Greece. International Journal of Learning, Teaching and Educational Research, 17(8), 89-106. https://doi.org/10.26803/ijlter.17.8.6

[77]Zein, M. (2016). Peran guru dalam pengembangan pembelajaran. Journal UIN- Alauddin, 5(2), 274285. https://doi.org/10.24252/ip.v5i2.3480

[78]Zhang, W., Wang, Y., Yang, L., \& Wang, C. (2020). Suspending classes without stopping learning: China's education emergency management policy in the COVID-19 outbreak. Journal of Risk and Financial Management, 13(3), 55. https://doi.org/10.3390/jrfm13030055 